MedieKultur | Journal of media and communication research | ISSN 1901-9726

Article - Theme section

\title{
Challenged by the state and the Internet Struggles for professionalism in Southeast Asian journalism
}

\section{Emilie Lehmann-Jacobsen}

MedieKultur 2017, 62, 18-34

Published by SMID | Society of Media researchers In Denmark | www.smid.dk The online version of this text can be found open access at www.mediekultur.dk

\begin{abstract}
As in other regions, journalism in Southeast Asia is under pressure. Journalists in many of the region's emerging markets have to develop their profession while struggling with changing market conditions, increasingly more demanding audiences, different degrees of authoritative states and growing competition from the Internet. Based on qualitative interviews and drawing on a combination of role theory and Pierre Bourdieu's field theory, this article compares the role performances of journalists in Singapore and Vietnam by looking into the different expectations journalists in the two countries meet. The article illustrates how journalists continue to feel most conflicted about conforming to state expectations for their profession. However, online actors encroaching on the journalistic field are beginning to have a progressively bigger impact. Though they push the boundaries and set the media agenda, journalists fear the online actors are changing the journalistic habitus, devaluing the journalistic capital and eroding years of progress toward professionalization.
\end{abstract}

\section{Keywords}

Journalists, professionalization, media regulation, Internet, field theory, role theory, Southeast Asia. 


\section{Introduction}

We are being berated on both sides. The government hates us [laughing], and our readers think we are just mouthpieces - it means we are doing something right, right?'

The quote above by a Singaporean online news editor highlights one of the key challenges media professionals in Southeast Asia are experiencing at the moment. The state plays a significant role in the media industry, and censorship as well as self-censorship is part of everyday life in the newsroom - something that is commonly being described in the region as a way of securing national values and in the West as suppression of press freedom. But the state is only one of several players that have an impact on the journalistic profession in the region. Economic growth has fostered a more affluent and demanding audience, and the rapid spread of information and communication technologies has changed the playing field dramatically. As in many other parts of the world, journalism in Southeast Asia is undergoing changes at accelerated speed. However, in contrast to journalism in Western parts of the world, these changes are happening in fields that are not yet fully developed and are still struggling to find their footing and positions in society.

Through a comparative study of the journalistic fields in Singapore and Vietnam, this article looks into the journalistic profession in Southeast Asia with the underlying argument that the region has a unique approach to journalism despite obvious differences between the two countries. Vietnam and Singapore represent countries at different developmental stages (Vietnam has recently been characterised as a low middle-income society, and Singapore is a high-income society). They are different sizes and have different forms of government. This makes them suitable for an investigation of media systemic similarities.

As this article will show, journalists in both countries fight a daily battle to maintain their professional status in fields that are constantly confronted by high expectations from the state and challenged by new online actors who do not necessarily know the 'rules of the game' or share the same journalistic values and ethics. Using a combination of field theory (Bourdieu, 1984; Bourdieu, 1993; Benson, 1998, Benson \& Neveu, 2005) and role theory (Thomas \& Biddle, 1966; Aubert, 1979; Biddle, 1979; Biddle, 1986) to understand how daily struggles within a journalistic field on a micro-level affect the structure and position of the field in social space, the article delves into two research questions: 1) who are the key agents influencing the role performance of journalists in Singapore and Vietnam, and 2) what impact do the expectations these agents hold about the performances have for the profession and the journalistic fields?

\section{Combining field theory with role theory}

In recent years, Pierre Bourdieu's field theory (1984, 1993, 2005) has gained increased recognition as an analytical tool within journalism studies (e.g., Benson \& Neveu, 2005; Benson, 2013; Willig, 2012; Willig et al., 2015). By viewing society as structured around the 
opposition between economic and cultural capital and differentiated into a number of semi-autonomous fields separated by their own specific logics and internal rules, Bourdieu provides a theoretical framework to understand how social action is structured in terms of power relations. This makes the theory useful for understanding how the profession of journalism in a country - or a region - relates, interacts and struggles with other fields in social space - in particular, the field of power, the state or states in question.

As the theory has primarily been used to understand journalism in Western democracies - France, in particular (see Bourdieu, 1998; Neveu, 2005; Champagne, 2005; Benson, 2005 , 2013), the journalistic field is generally viewed as a subfield within the field of cultural production together with the arts and sciences. As a part of this field, the journalistic field also automatically belongs to the field of power (see figure 1).

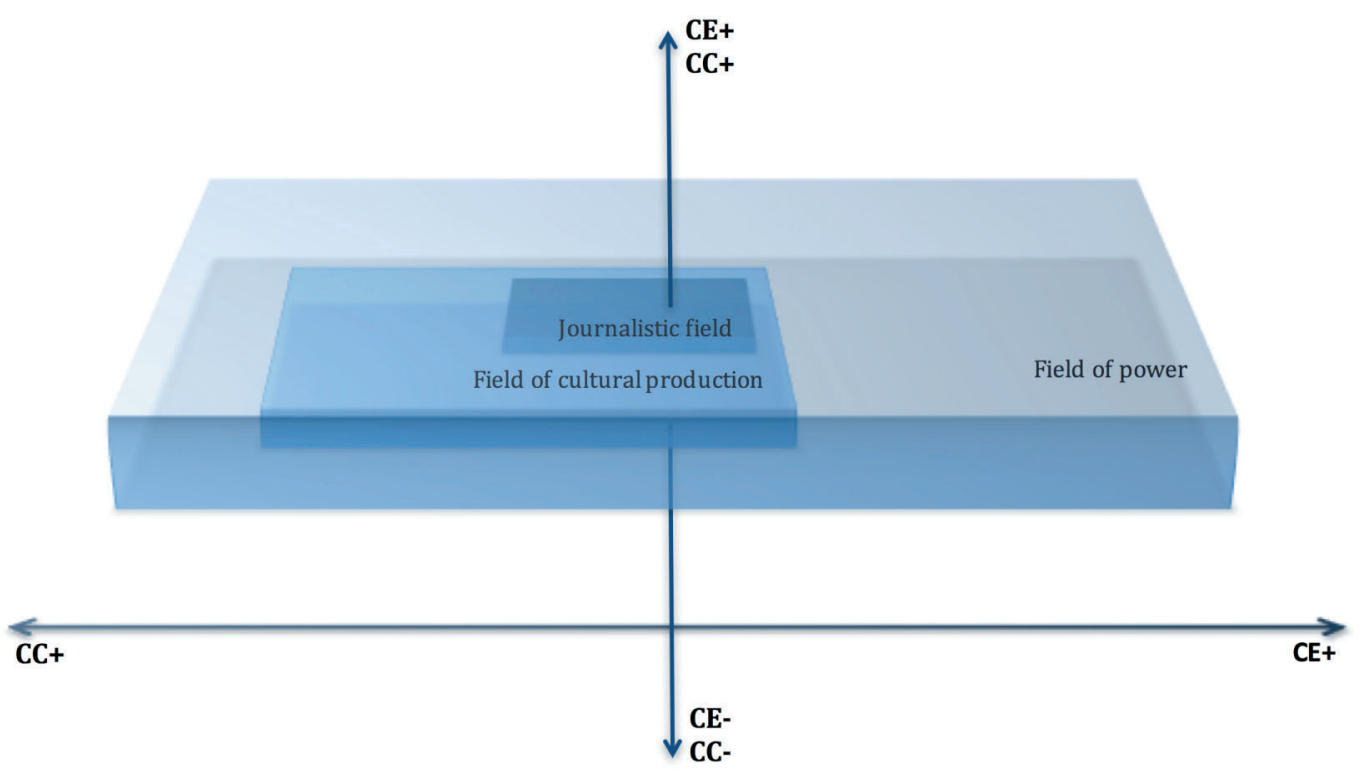

Fig. 1: Structure of fields in social space. Based on Benson (1998, p. 466). The model is to be viewed as three-dimensional with the journalistic field hovering within the field of cultural production and the field of cultural production hovering within the field of power. The vertical line indicates the total amount of capital and the horizontal line indicates the type of capital (CE = economic capital, $C C=$ cultural capital).

Where the journalistic field is positioned within the field of power is, according to Benson (2013, p. 25), a question of relative "proximity" to "the nonmarket or civil field and the capitalist market field". However, as he goes on to note, it is rarely as simple as that. First of all, fields overlap despite their distinct features and autonomy. Second, the state has a say in both non-market and market activities through laws and regulations, which is why it 
is impossible to talk of fields as being directed by either state or market logics. And, third, the external logics influencing the field's position are both material and symbolic - and all forms should be taken into consideration when locating a field's position.

A general opposition between a heteronomous pole and an autonomous pole structures the agents within a field. The heteronomous pole represents the forces external to the field, the economic and political capital, while the autonomous pole represents capital unique to the field, the field's cultural and symbolic capital. The power and position of a social agent will be determined "by his or her social capital (membership of networks, social connections, friendships with the 'right' people), cultural capital (skills, knowledge, educational background), or economic capital (command over economic resources)" (Dickinson, 2008, p. 1387). In this understanding, the capital, which can both be of the material and the immaterial kind, is something that the agent uses in the field when interacting with other agents and something that can help explain internal hierarchies and structures within a field. In addition, the habitus, the "structuring structure, which organizes practices and the perception of practices" (Bourdieu, 1984, p. 170), sums up the agent's predispositions to play the game in field. Or, as Willig (2016, p. 54) describes it, habitus is "synthesizing the history, experiences, and lived life of an individual as an 'embodied sense of the game'". Driven by their individual habitus and with different forms of acquired capitals at hand, social agents compete over the dominant positions within a field. Thus, fields should be seen as sites of struggles (Bourdieu, 1993), always in flux and constantly changing. To understand a field, therefore, one must understand the agents within the field and the different forces that drive them.

In the journalistic field, the habitus unique for the field, the journalistic habitus, implies understanding the journalistic game and knowing what is necessary to produce news. Capital can come in different forms, such as economic, cultural, social and symbolic capital - symbolic capital, in this case, means journalistic capital. Journalistic capital, in the words of Willig (2012, p. 374), can be seen as "the resources the agent (media or journalist) can put into the game, resources that are recognised in the field and by the other agents in the field". It is a form of capital closely connected to peer recognition: "Having a lot of journalistic capital means having a lot of respect from journalist colleagues and having a good position internally in the journalistic hierarchy" (ibid., p. 380). But peers are not the only ones awarding agents in the journalistic field with capital. As the journalistic field engages with agents and forces from other fields with other positions in social space, other forms of capital besides journalistic capital may be of value to journalists. Møller Hartley's research on online journalists, for instance, shows how the concept of capital can be used as an analytical dimension to understand hierarchies of journalistic genres and subfields (Møller Hartley, 2013). By evaluating the value of different forms of capital and tracing the origin of the capital, a field's relation to other fields and social agents becomes more visible.

But how do agents in a field validate their professional (in this case, journalistic) habitus. And how do they acquire and make use of their capital? Or, in other words, how do agents 
acquire the resources that are necessary in struggles over positions in the field, the fight over power and resources? Whereas habitus is a product of our socialisation, a combination of previous experiences, upbringing and education, capital is something that we must acquire. It does not come out of nowhere but is given to us - or taken from us - through interaction. As this article proposes, role theory might provide the solution since it gives us the potential to look at the different agents engaging with the position-holder and evaluating their influence on the incumbent's role performance. By looking at the key agents in the incumbent's so-called role set, the norm senders, we can uncover and analyse the different expectations the actor encounters and the capital used to enforce said expectations.

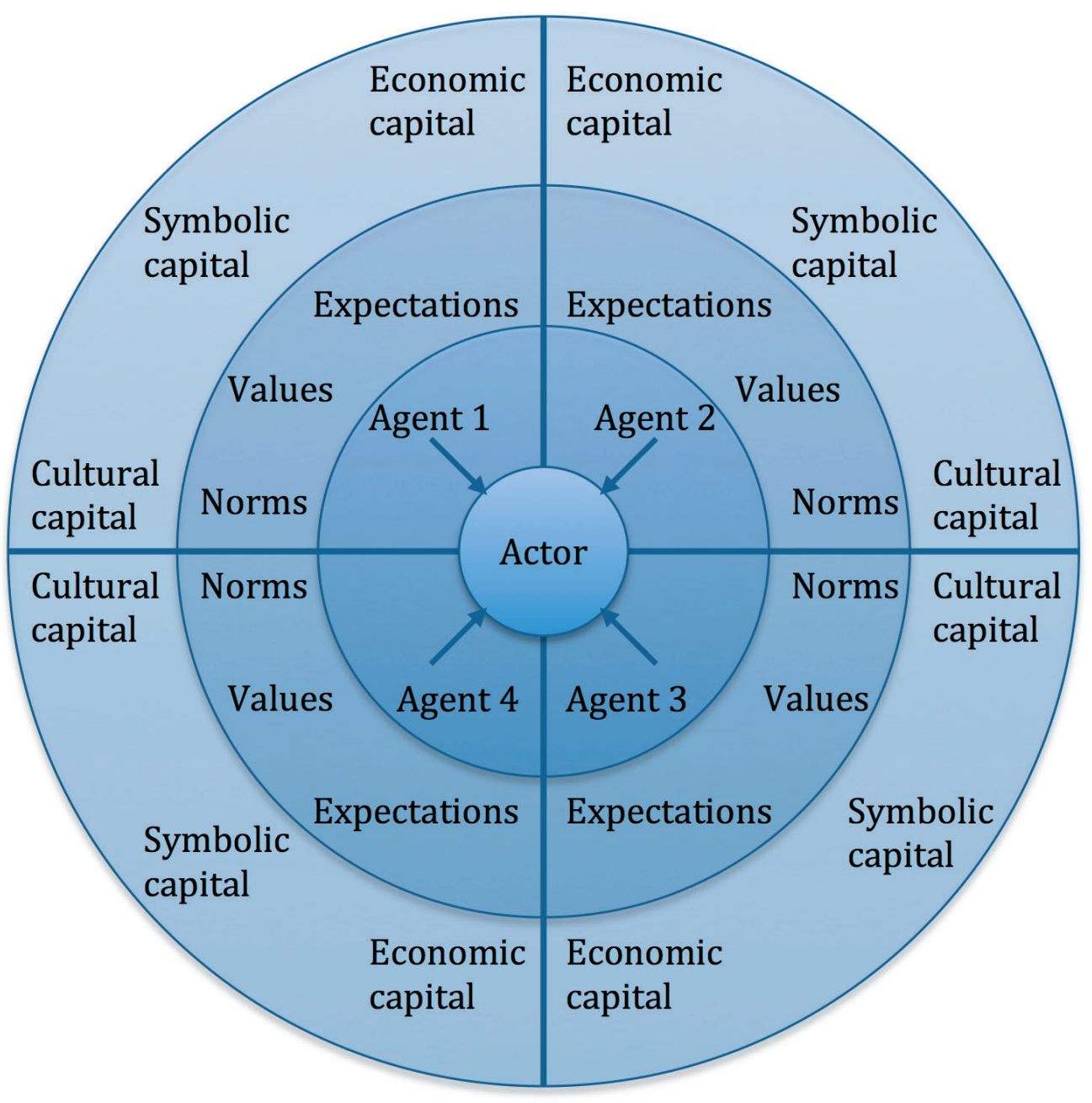

Fig. 2: Dimensions of expectations of a role performance. The figure shows how an actor encounters expectations from different norm senders. These norm senders are backing their individual norms, values and expectations with different forms of capital that the actor will have to evaluate before deciding with whom to conform. 
Generally, role theory is used to explain how "individuals who occupy particular social positions are expected to behave and how they expect others to behave" (Hindin, 2007, under "Role theory"). By knowing a person's role, one builds a set of expectations for the person's behavior based on one's own ideas and assumptions as to what the role consists of. Since a role can only exist in a context and is created through interaction, the behavior of an individual must be examined "in terms of how it is shaped by the demands and rules of others, by their sanctions for his confirming and nonconfirming behavior, and by the individual's own understanding and conceptions of what his behavior should be" (Thomas \& Biddle, 1966, p. 4). The position-holder may experience many different and, sometimes, competing expectations for his or her role performance because the norm senders reward and sanction behavior based on their own backgrounds, positions and agendas. These experienced difficulties in fulfilling role obligations, defined as role strain or role conflict, are unavoidable and inherent in the social system.

In order to act, a person must resolve these conflicts and decide on a coping strategy based on an evaluation of the differing sets of expectations that he or she encounters. Aubert (1979) argues that the outcome of the conflicts relies on the power of the norm senders. The power may stem from the emotional relationship to the norm sender, the competency of the norm sender and the available sanctions of the norm sender (ibid., p. 90). Depending on the type of role and the norm sender in question, organisational factors and personality factors may also have an effect (Kahn et al., 1966). In the end, Aubert (1979, p. 90) argues, the incumbent will most likely conform to the norm sender with the most power and adjust his or her performance accordingly.

Adding Bourdieu to the picture, the power of the norm senders might be understood in terms of capital. The norm senders can enforce their expectations on the position-holder by employing their capital. The incumbent will then have to evaluate the power, or the capital, of the norm senders before deciding with whom to conform and, ultimately, what role to perform. Identifying the key norm senders, analysing their expectations for the actor and their capital, therefore, will help reveal the struggles over role performances in a field. As this article argues, mapping these micro-level struggles (see figure 2) will make it easier to understand the macro-level struggles in the entire field and its position in social space.

\section{Locating norm senders in Singapore and Vietnam}

To uncover the key norm senders for journalists in Singapore and Vietnam and to understand the different expectations they encounter, qualitative interviews were undertaken with journalists and editors from the established media in the two countries. Interviews with new online actors such as bloggers and self-labelled citizen journalists were added to broaden the understanding of the complex journalistic field in the two countries, where the amateur and professional parts of the field interact, support and confront each other. 
A total of 40 interviews were conducted during five different field trips in the two countries in June-July and December 2014, January 2015 and February-March 2016. All of the interviews were conducted face-to-face on the basis of a semi-structured interview guide, giving the interviews a conversation-like feeling and making it possible for the interviewer to adjust questions depending on the interviewee's time, responses and willingness to share more sensitive information and experiences. As the media in both countries are supervised and managed to different degrees by the state, journalism is considered a sensitive subject in many cases. Therefore, establishing trust between the interviewer and the interviewees became an important issue. In an attempt to create the optimal conditions, an active interview approach was applied, and all interviewees were guaranteed full anonymity. Though interviewees' positions will be mentioned when quotes ${ }^{2}$ are presented, their names and media organisations are withheld.

\section{Introducing media in Singapore and Vietnam}

The media in Singapore are generally viewed as being controlled and micromanaged by the government (Reporters Without Borders, 2016a; Freedom House, 2015a). The structure of the media markets - which contain only two public companies, Singapore Press Holdings (SPH) and MediaCorp, that divide the country's 16 newspapers, 7 television stations and 14 radio channels between them ${ }^{3}$ - is frowned upon by international NGOs and institutions that work with press freedom. In particular, this is due to the fact that the two companies are closely linked to the government. MediaCorp is government-owned through the state's investment company Temasek Holdings and Singapore Press Holdings, although a listed company, is kept in check by an intricate shareholder scheme providing the state with power over the distribution of management shares. Not surprisingly, Singapore is ranked in the bottom quarter of international press freedom indexes (Reporters Without Borders, 2016a), and the media are typically described as a mouthpiece of the government. The picture, however, is somewhat more nuanced than that. As a young country with a small and very diverse population, four official languages (Chinese, Malay, English and Tamil) and numerous religions, the government has from the beginning seen it as its primary task to secure harmony and security for its 5.3 million citizens. One of the key tools for doing that has been and continues to be through a form of control of the media: officially, with laws and regulations ${ }^{4}$ and requirements of annually renewed media licenses and, unofficially, with unwritten rules, the so-called "out-of-bound" or OB markers. Or as the former Prime Minister Lee Kuan Yew famously put it in an address to the General Assembly of the International Press Institute in Helsinki, Finland on June 9, 1971:

The mass media can help to present Singapore's problems simply and clearly and then explain how if they support certain programmes and policies these problems can be solved. More important, we want the mass media to reinforce, not to undermine, the cultural values 
and social attitudes being inculcated in our schools and universities. The mass media can create a mood in which people become keen to acquire the knowledge, skills and disciplines of advanced countries. Without these, we can never hope to raise the standards of living of our people (Yew, 1971).

Like the media in Singapore, the media in Vietnam are typically seen as not just being controlled but directly managed by the government, since all media institutions must by law be affiliated with the ruling Communist Party (Law on Media, 1999). Private ownership of media is officially not allowed, and all of the country's 1,170 press agencies (who, among other things, publish 199 local, regional and national newspapers, 659 magazines, and 105 online newspapers), and 66 broadcasters ${ }^{5}$ are required to secure a media license. However, since the introduction of the Doi Moi ${ }^{6}$ reforms in 1986, the media have been subject to market conditions as the government began to cease its subsidies and allow the media "to seek other financial resources including those from advertisers and subscribers" (Huong, 2008, p. 148). Like Singapore, Vietnam is to be found among the lowest-ranked countries when it comes to press freedom (Reporters Without Borders, 2016b; Freedom House, 2015b), and the country regularly experiences criticism from international community in regards to their treatment of the media and journalists. The Vietnamese government justifies its approach to the media with a different view on what the media are and should be. In the first article of Vietnam's Law on Media (1999), the media operating within the Socialist Republic of Vietnam is characterised as "the essential means of providing public information in relation to social life; [...] the mouth piece [sic] of Party organisations, State bodies and social organisations [...], and a forum for the people". As in Singapore, the government sees the media as a key player in helping to secure prosperity and development for its more than 90 million inhabitants; something that, in their view, is simply not possible without some form of state supervision. Again, this form of state supervision and intervention exists on both an official level and an unofficial level.

\section{Comparing the challenges to the journalistic fields in Singapore and Vietnam}

On a macro-level, the journalistic fields in Vietnam and Singapore are both placed within the larger field of power, since they possess high volumes of both economic and symbolic resources. Both non-market logics and market logics influence the fields in the two countries. Both are controlled and supervised by their respective states while simultaneously being highly dependent on external market forces. Though both fields are regulated by the state in various ways, they receive very few subsidies and rely almost exclusively on sales and advertising to secure revenue. Yet, since all media institutions in Vietnam must be affiliated with the Communist Party, the journalistic field in Vietnam appears to be farther from the market pole than the journalistic field in Singapore and more dependent on the civic field. Political capital, therefore, also seems to be of higher value in the Vietnamese journalistic 
field, whereas the Singaporean journalistic field appears to place higher value on economic capital. However, the journalistic field in Singapore does not operate on "pure" market principles because the state has several types of laws and regulations in place that organise the media markets. In comparison, for instance, to the U.S. journalistic field, both the Vietnamese and the Singaporean journalistic fields are much farther removed from the market pole and are more encompassed by the civic field. From a macro perspective, the external resources, or capital, that appear to be operative within the journalistic fields of Vietnam and Singapore are primarily of symbolic nature. Though economic resources are beginning to have a bigger influence and the fields are gradually being pulled more in a direction of the market pole (in part, also on initiative of the states), symbolic resources and, especially, political capital continue to play a vital part. It should be noted that political capital is most apparent on an institutional level, whereas symbolic capital - e.g., in the form of journalistic capital - is deemed of more value when viewed at the level of the individual agents in the journalistic fields, the editors and journalists, as will be discussed in the following section.

From the macro-level we move to the micro-level to uncover the key norm senders in journalists' role sets. Four primary agents or groups are identified as having most influence on the role performance of journalists in both countries: other actors in the journalistic field (peers), the state, the public, and, last but not least, the new online actors such as bloggers, self-labelled citizen journalists and highly-active social media users (see figure 3a and $3 \mathrm{~b}$ below).

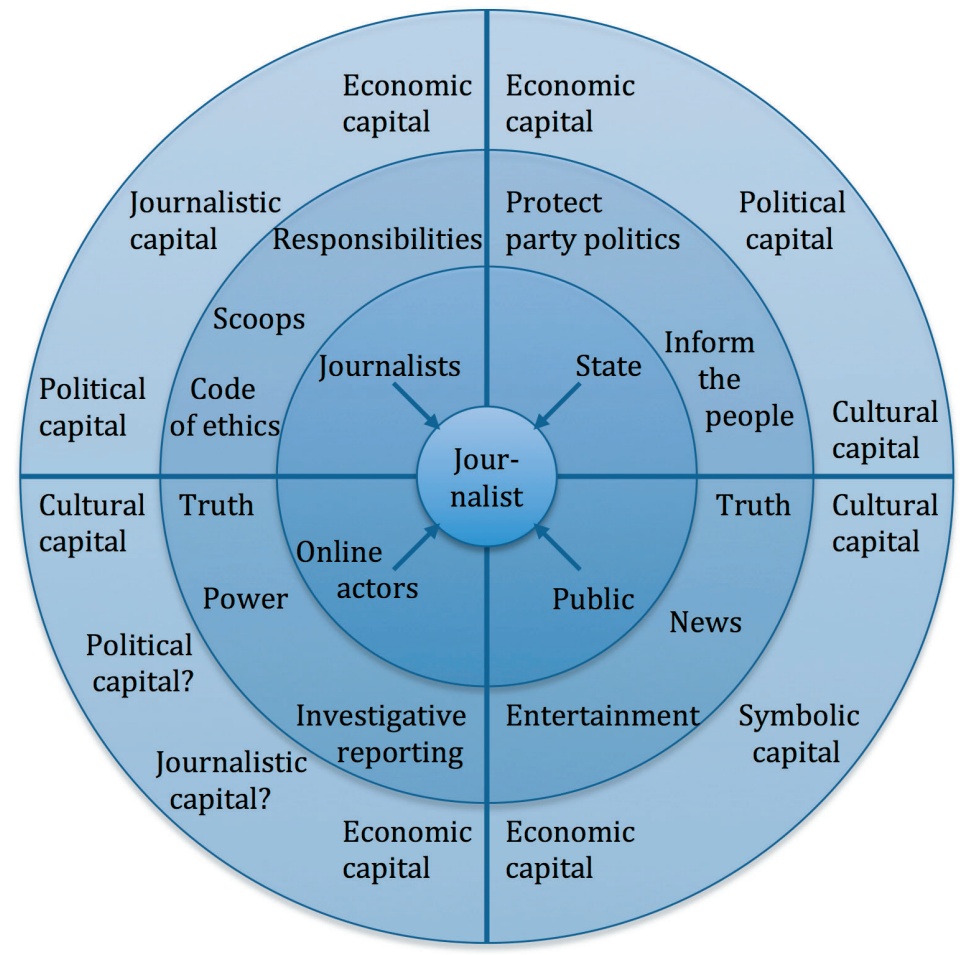

Fig. 3a: Key norm senders in Singapore 


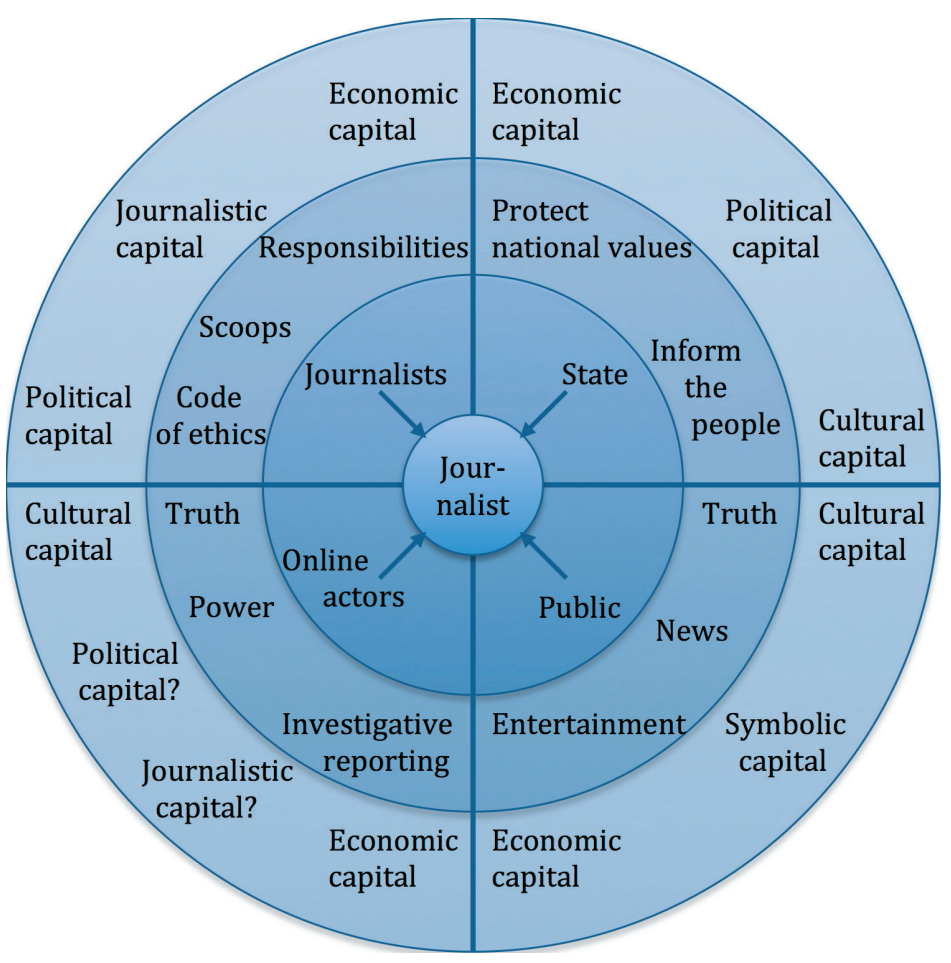

Fig. 3b: Key norm senders in Vietnam

Though the key norm senders are the same in both countries, their impact on the journalistic fields differ. Because the journalistic field in Singapore is more established, the journalists there seem better prepared to deal with the conflicting expectations they meet than their colleagues in Vietnam.

\section{Peers as norm senders}

Journalists in both countries naturally try to conform to some of the expectations they meet from their journalistic peers in the hope of receiving journalistic capital. In both countries, journalists and editors who dare to push the boundaries, to do investigative reporting and to make attempts at exposing wrongdoings in society are highly admired. However, these journalists also test the system and will only continue to be rewarded with journalistic capital as long as they adhere to the ethical norms and standards of the profession, or, in the case of Vietnam, as long as they do not experience any backlash from the Party. According to the media professionals, it is all a matter of balance: a good journalist tests the limits and pushes the boundaries but always in a responsible way - without inflicting any harm on the profession. Or as a seasoned reporter from Vietnam puts it: 
You have to have this responsibility on the journalists. If you don't have this responsibility, what are you thinking? You have nothing to do without your values. You just take advantage of this job. ${ }^{8}$

Interestingly, the journalists are not just trying to live up to national ideals of "the good journalist". Most of the participants in this study also display some form of admiration of a universal version of "the good journalist" - a sort of representative of journalists all over the world - even though most would admit that none exists. Nonetheless, the journalists in both countries try to position themselves with respect to this universal ideal journalist and argue how they, despite constrictions on their national field of journalism, are still able to aspire to do "good journalism". Though they rarely get recognition from their international peers, they clearly feel that they belong to an international version of the journalistic field and that they should be entitled to journalistic capital from this field as well.

\section{The public as norm senders}

Expectations from the public are also very important for journalists in both countries, who feel they have a responsibility towards not just their target audiences but also the wider public. There is a common consensus that the media's first priority is to provide the public with relevant information and analyses. Even though journalists by nature seek scoops and idealise investigative reporting, they know that they also have a more "mundane" role to play when it comes to serving the public. A Singaporean online editor clarifies:

\footnotetext{
I think we can all agree that news are [sic] more than political news. So, we also perform a social role because we probably carry news that are [sic] not carried by other websites. We carry public information about new bus routes, the mundane things like new shopping centre's opening; carry public information about public offices closed for the holiday. You know, these kind of things you probably don't find people using resources to write [...] [I]t might evolve 15-20 years down the road this role is irrelevant, but, at the moment, people still like the newspapers to convey this kind of information, right??
}

In both countries, however, journalists and editors find it increasingly difficult to meet the expectations of the public. As in many other countries around the world, the younger generations are becoming less interested in paying for journalistic content. Moreover, with the Internet making it easier to express opinions and post comments in connection to published stories, journalists have to deal with criticism from the public. This lack of appreciation is not just experienced on an economic level, journalists also feel cheated of the symbolic journalistic capital they used to receive from the public: capital that, in some cases, now goes to their online competitors who, in the view of critics, dare play the role of the watchdog and take on some of the more sensitive issues in society. 


\section{The state as a norm sender}

With the media industry being closely tied to the state in both countries, expectations from this agent (enforced primarily by political capital) play a huge role. Journalists and editors are very much aware of the state's influence and know that working with the state is part of the job. However, they do not necessarily see this as a problem. Many of the journalists and editors feel they have a responsibility toward the nation and its inhabitants: a responsibility that requires them to frame stories in a different way than their colleagues in other countries might or to emphasise certain stories over others to promote national values - similar to what is expected of others working within the state apparatus. A senior journalist in Singapore explains:

[S]elf censorship is definitely there, but that is just the way it is here and that doesn't mean that I can't... that I'm dissatisfied working as a journalist. No, it is not like I can't tell certain kinds of stories or if I see something I can't write about it - it is not like that. It is just that I need to be responsible when I do that. I need to be intuitive and I make sure that when I write that story that it doesn't come back to haunt me. ${ }^{10}$

This does not mean that the journalists are satisfied or accept all restrictions to their work. They do sometimes feel constricted in their responsibilities and express discontent about having to abandon stories or perform varying degrees of self-censorship. In particular, they feel a pull towards living up to the ideals of the universal "good journalist". As a young Vietnamese online reporter puts it:

\footnotetext{
Clearly, this media environment and the mechanisms that is [sic] controlling it now doesn't appreciate it and doesn't encourage the journalists to do the best journalism that they can. They can do good journalism, but the best journalism, that the readers, that the audience deserve, it is not encouraged here in the system. Do Vietnamese people deserve the same journalism as people around the world, as in Denmark? Of course, they do. But it is not encouraged here. Because, clearly, understandably, the ones with power, they don't want anything to threaten them. ${ }^{11}$
}

Although journalists express discontent in both countries, the Vietnamese seem more frustrated than their colleagues in Singapore. Journalists in Singapore appear to be more comfortable with their role(s) and responsibilities. They have a better grasp of their boundaries and of the state's expectations for their role performance. Since the boundaries and the unofficial rules are less clear in Vietnam, the journalistic field appears unstable. Despite the field's attempts to define itself and become more professional, the irresolution of the state makes it difficult for journalists to perceive their role(s) in the field. It also seems to be a matter of age and experience. The more seasoned journalists, who have become accustomed to the workings of the field, the rules of the game or the doxa as Bourdieu would label them, appear less conflicted. That does not mean that they do not question the 
requirements or restrictions they are feel they are encountering from the state. They are just better at working with them.

\section{Online actors as norm senders}

Finally, there are the new online actors, who are beginning to have a progressively bigger impact on the journalists' role performances. Journalists and editors in both countries feel very conflicted about these new actors. On one hand, they recognise that they have come to play an important role in the media industry. They are helping to push the boundaries and set the media agenda, which, until recently, was something exclusively for the established media to do (in collaboration with the government or the Party). On the other hand, the professionals are not overly enthusiastic about losing parts of their journalistic capital to a group of amateurs who do not follow the same 'rules of the game', the doxa of the field, or live by the same code of ethics. Of the increased competition, an editor-in-chief from Singapore says:

\footnotetext{
I can't say they are not changing the game because my reporters look at what's happening, what they write at [sic] their websites. So, it does affect our coverage, what we do, etcetera. But in a way they don't, in my opinion, uphold the same professional standards as we do. I am not saying they are unprofessional - they are just bloggers, you know? They do it in their spare time, they don't check their facts, they repeat things they hear without doublechecking. So, they have different standards. [...] But does it affect us? Of course, it does. Because they will break stories that we will have to chase after and then find 'oh shit, this is a half-truth' and you have to put the other half of the truth. ${ }^{12}$
}

In addition, there is a concern that the public is not always capable of distinguishing professional content from amateur content. This does not only hurt the journalistic profession (which devalues the journalistic capital of the journalists) but also the public debate because people are not being exposed to information of a sufficient quality. Journalists fear that too much responsibility is being placed on the public's abilities to fact-check and verify information - a job that should be placed in the hands of media professionals. Or in the words of a senior editor from Vietnam:

In the capacity of monitoring the media, they are doing a good job; but, in the role of producing news, they are doing a very bad job. Because it is full of biases, biased reporting, full of speculation, full of misleading information. So, people will need the filter. The filtering role of the media is still there. You still need the real media - the professional media to do the real job. ${ }^{13}$

Again, the journalistic field in Singapore seems better equipped to handle the challenges journalists face from these new norm senders. But the fight to maintain the profession remains the same in both countries: the professional journalists are very keen on uphold- 
ing the boundaries of their profession despite competition from the online sphere. They appreciate the helping hand in challenging the media agenda but refuse to let go of their professionalism - however fragile it may be.

\section{From challenges to potential changes}

The internal struggles of the journalistic fields in both countries are not without consequences for their position in social space. With new actors challenging the journalistic habitus and devaluing traditional journalistic capital by assuming some of the former key responsibilities of journalists (such as breaking news, getting scoops and pushing the boundaries of accepted content), the journalistic fields of Singapore and Vietnam have been forced to undergo changes.

On a micro-level, traditional, professional journalists are now no longer the only players in the field. The online actors are beginning to break down the boundaries and engage in struggles over dominant positions in the fields. The professional journalists try to fight the intruders by invoking the journalistic doxa and stressing the need for journalistic ethics and values. In a less professionalised field, Vietnamese journalists seem to experience more difficulties in keeping the new players at bay. Given the substantial, variegated Vietnamese media market, the field appears more divided and less geared toward staying the course and developing in the direction of other journalistic fields. The Singaporean journalists appear better equipped to deal with the new players in the field. This seems to be due to the regulatory framework put in motion by the government, which requires online platforms of a certain size to register for a media license. With a better sense of coherence among its agents, the field is stronger, and the fear of losing control over the journalistic habitus is slighter.

On a macro-level, the journalistic fields of Singapore and Vietnam are both being pulled in new directions. The internal struggles on a micro-level send ripple effects throughout the system, and the fields are forced to move. Perhaps, one could argue, in a more autonomous direction - away from the civic pole and closer to the market pole - as a consequence of the new ways in which the media agenda is being created and as a result of the online actors' assistance with breaking down the visible and invisible boundaries of acceptable news content. The state control over the fields is diminishing, and the fields are trying to take the reins. However, as the fields become more diversified and new players are trying to take control of the journalistic habitus, the fields seem less stable and their power and current positions in social space are threatened. If the fields are to survive in their current forms and avoid either annihilation or fragmentation, more cohesion is needed. Even though the internal struggles are the fuel that power the fields, too much incongruity may end up causing irreversible damage to the professionalization project for which journalists in both countries continue to fight. 


\section{Conclusion}

This article set out to uncover the key norm senders in the role set of journalists in Singapore and Vietnam by analysing what their differing expectations to the journalistic fields on micro- and macro-levels. By combining Bourdieu's concept of field theory with role theory, the article attempted to develop a framework to understand how daily struggles on a micro-level affect the structure and position of the journalistic field in social space. With different forms of capital at hand, the key norm senders challenge the journalists in their role performance, which affects not only the journalistic habitus and capital but also the fields themselves.

Despite differences in size, governmental structure and level of development, Singapore and Vietnam share many of the same challenges to their journalistic fields. An evaluation of the expectations journalists in both countries encounter from key norm senders shows that journalists continue to conform the most to the state's expectations and adjust their role performance accordingly. However, their performance is also being challenged by a new group of online actors, who impose on their field, make changes in the journalistic habitus and devalue journalistic capital. These new actors may push the journalistic fields in both countries in a more autonomous direction away from the state while possibly also altering the entire profession in the process, eroding years of progress toward professionalization.

While the Singaporean journalistic field seems better prepared to face the challenges, secure its boundaries and defend its unique habitus and capital, the Vietnamese field appears more vulnerable. With a professionalization process that is lagging behind compared to Singapore, the actors lack a sense of coherence, making the struggles more difficult for the Vietnamese journalists to cope with and the field less robust. What the consequences will be for the field in the long run is difficult to say; but, without a strong coherence and clear boundaries, the confrontations could completely change the current path of the developing profession. The Vietnamese journalists may not be alone with this challenge. As many other countries in Southeast Asia are dealing with similar confrontations, the journalistic fields in the entire region may be on the move. However, more research and investigations into the individual fields are needed to create a broader understanding of the future of the journalistic profession in Southeast Asia.

\section{Notes}

1 Interview carried out on January 26, 2015 with a Singaporean online news editor based in Singapore.

2 All quotes are presented as they were delivered during the interviews. This - along with the fact that English is not the first language of most of the interviewees - explains many of the grammatical errors and misspeaks. 
3 Besides the legacy media, Singapore has 14 officially recognised online media. The 14 sites have been identified by the Media Development Authority as having met the criteria for needing a license under the government's online licensing framework, which came into effect June 1, 2013.

4 Most importantly, the Newspapers and Printing Presses Act of 1974, the Broadcasting Act of 1994, the Undesirable Publications Act of 1967 and the Defamation Act of 1957.

5 Figures as of December 31, 2015 released by the Ministry of Information and Communications. Retrieved June 29, 2016, from http://mic.gov.vn/solieubaocao/Pages/TinTuc/116095/Tinh-hinh-phat-trien-linhvuc-bao-chi-va-phat-thanh-truyen-hinh-nam-2015.html .

6 Economic and political reforms introduced in Vietnam with the initial goal of creating a socialist-oriented market economy similar to that of China.

7 Most importantly, the Law on Media of 1999.

8 Interview carried out on March 9, 2016 with a Vietnamese journalist based in Ho Chi Minh City, Vietnam.

9 Interview carried out on January 26, 2015 with a Singaporean online news editor based in Singapore.

10 Interview carried out on July 2, 2014 with a Singaporean TV editor and journalist based in Singapore.

11 Interview carried out on December 12, 2014 with a Vietnamese online journalist based in Hanoi, Vietnam.

12 Interview carried out on January 30, 2015 with a Singaporean editor-in-chief based in Singapore.

13 Interview carried out on December 19, 2014 with a Vietnamese senior editor based in Ho Chi Minh City, Vietnam.

\section{References}

Aubert, W. (1979). Sosiologi 1. Sosialt samspill. Oslo: Universitetsforlaget.

Benson, R. (1998). Field theory in a comparative context: A new paradigm for media studies. Theory and Society, 28, 463-498.

Benson, R., \& Neveu, E. (2005). Bourdieu and the Journalistic Field. Cambridge: Polity Press.

Benson, R. (2013). Shaping Immigration News: A French-American Comparison. Cambridge: Cambridge University Press.

Bourdieu, P. (1984). Distinction: A Social Critique of the Judgment of Taste. London: Routledge \& Kegan Paul Ltd.

Bourdieu, P. (1993). The Field of Cultural Production. Cambridge: Polity Press.

Bourdieu, P. (1998). On Television and Journalism. London: Pluto Press.

Bourdieu, P. (2005). The political field, the social science field, and the journalistic field. In R. Benson, \& E. Neveu (Eds.), Bourdieu and the Journalistic Field (pp. 29-47). Cambridge: Polity Press.

Champagne, P. (2005). The 'double dependency': The journalistic field between politics and the market. In R. Benson, \& E. Neveu (Eds.), Bourdieu and the Journalistic Field (pp. 48-63). Cambridge: Polity Press.

Dickinson, R. (2008). Studying the sociology of journalists: The journalistic field and the news world. Sociology Compass, 2(5), 1383-1399.

Freedom House. 2015a. Freedom in the World 2015: Singapore. Retrieved June 30, 2016, from https:// freedomhouse.org/report/freedom-world/2015/singapore.

Freedom House. 2015b. Freedom in the World 2015: Singapore. Retrieved June 30, 2016, from https:// freedomhouse.org/report/freedom-world/2015/vietnam.

Hindin, M.J. (2007). Role theory. In G. Ritzer (Ed.), Blackwell Encyclopedia of Sociology. Retrieved August 20, 2015, from http://www.sociologyencyclopedia.com/public/. 
Huong, D.T.T. (2008). Radio and its listenership in the Internet Age - Case study of the Voice of Vietnam (VOV) and VOVNews. PhD diss., Bournemouth University.

Kahn, R.L., Wolfe, D.M., Quinn, R.P., Snoek, J.D., \& Rosenthal, R.A. (1966). Adjustment to role conflict and ambiguity in organizations. In E. J. Thomas, \& B.J. Biddle (Eds.), Role Theory: Concepts and Research (pp. 277-282). New York: John Wiley \& Sons.

Møller Hartley, J. (2013). The online journalist between ideals and audiences. Journalism Practice, 7(5), 572587. Doi: 10.1080/17512786.2012.755386.

Neveu, E. (2005). Bourdieu, the Frankfurt School, and cultural studies: On some misunderstandings. In R. Benson, \& E. Neveu, (Eds.), Bourdieu and the Journalistic Field (pp. 195-213). Cambridge: Polity Press.

Thomas, E.J., \& Biddle, B. J. (1966). The nature and history of role theory. In E.J. Thomas, \& B.J. Biddle (Eds.), Role Theory: Concepts and Research (pp. 3-19). New York: John Wiley \& Sons.

Reporters Without Borders. (2016a). Press Freedom Index: Singapore. Retrieved June 30, 2016, from https:// rsf.org/en/singapore.

Reporters Without Borders. (2016b). Press Freedom Index: Vietnam. Retrieved June 30, 2016, from https:// rsf.org/en/vietnam.

Yew, L.K. (1971). The mass media and new countries. Address to the General Assembly of the International Press Institute, Helsinki, June 9, 1971.

Willig, I. (2012). Newsroom ethnography in a field perspective. Journalism, 14(3), 372-387. Doi: $10.1177 / 1464884912442638$.

Willig, I., Waltorp, K., \& Møller Hartley, J. (2015). Field theory approaches to new media practices: An introduction and some theoretical considerations. MedieKultur, 31(58), 1-12.

Willig, I. (2016). Field theory and media production: A bridge-building strategy. In C. Paterson, D. Lee, A. Saha, \& A. Zoellner (Eds.), Advancing Media Production Research (pp. 53-67). Palgrave Macmillan.

Emilie Lehmann-Jacobsen PhD fellow

Department of Media, Cognition and Communication

University of Copenhagen emilielj@hum.ku.dk 